\title{
Clinical and Epidemiological Features of Acute Corrosive Poisonings
}

\author{
Andon Chibishev ${ }^{1}$, Zenina Pareska ${ }^{1}$, Vesna Chibisheva ${ }^{2}$, Natasa Simonovska ${ }^{1}$ \\ University Clinic of Toxicology, Clinical Center Skopje, Republic of Macedonia ${ }^{1}$ \\ University "Ss Cyril and Metodius", Medical faculty, Skopje, Republic of Macedonia²
}

ackground: the ingestion of chemical agents, of caustic nature, represents a

D serious problem for clinical toxicology. If the ingestion doesn't cause death during the acute period, it will most often cause severe side effects in the upper gastrointestinal tract during the chronic phase. Aims: The purpose of this study is to show the clinical, epidemiological and socio-economical characteristics seen in acute corrosive poisonings such as ingested caustic agents, causes for abuse and most consequential complications. Material and methods: a ten year medical data was constructed and collected (2000-2009) from patients with acute corrosive poisonings who were hospitalized and treated in the University Clinic of toxicology and urgent internal medicine in Skopje, Republic of Macedonia. The variables included were: age, sex, type of poisonings and percentage of late post-corrosive complications. Results: In the study, 735 patients files were analyzed, collected in a period of ten years. The mean age of patients is $32.9 \pm 15.6$ years. Majority of patients ingested hydrochloric acid $(\mathrm{HCl} ; \mathrm{n}=354 ; 48,16 \%)$. Conclusion: Demographic, diagnostic and therapeutic findings in acute corrosive poisonings are found to be similar to the findings observed in the referenced literature. Conclusively, women between 14 and 30 years old represent a high risk group; hydrochloric acid is the most often abused agent; and high percentage of post-corrosive complications are observed. Key words: corrosive substances; esophageal injuries; post-corrosive stenosis ; esophagogastroduodenoscopy.

Corresponding author: Andon Chibishev, PhD. University Clinic for Toxicology,Clinical Centre, Vodnjanska 17, 1000 Skopje,Republic of Macedonia. Tel: +389 23211 072 + +389 23237 504 + +389 23147635 . +389 70387 040. +389 75223 223. E-mail: toksikourgentna@gmail.com

\section{INTRODUCTION}

Acute corrosive poisonings are a serious socio-medical problem since they can result in severe oral, pharyngeal, esophageal and gastric lesions. The extend of the chemical injuries causing this lesions, depends on: the nature, amount and concentration of the corrosive agent, length of exposure and act of swallowing (1). A waste number of patients faced mild post-corrosive in- juries and most often recover without serious complications (2). Nonetheless, a significant number of poisonings result in severe chemical injuries and complications of the upper gastrointestinal tract and a high percentage of mortality. These outcomes are most often due to tracheal necrosis, perforation of the esophagus and stomach, and the consequential mediastinitis and peritonitis (3). Corrosive poisonings most often are a result of suicide attempts, however they can happen accidentally to children and in individuals in acute alcoholic state (4). After the acute period, post-corrosive injuries, during the chronic phase may lead to esophageal or gastric stenosis, which inhibits normal food intake (5).

The shared opinion between authors is that algorithms for treating patients with corrosive poisonings depend on results from the urgent esophagogastroduodenoscopy. There are numerous endoscopic classifications of postcorrosive injuries of the upper GIT. In general the treatment is conservative for patients with minor clinical side effects while patients with life-threatening complications need surgical intervention $(6,7)$. The approach is multidisciplinary and it depends on the severity of post-corrosive injuries, complications and patients' state.

According to comparative research, in the USA the incidence of corrosive poisonings is decreasing, while in India and Turkey is increasing (8). An increased number of corrosive poisonings is also reported in Macedonia (8). The aim of this study is to implicate the types of diagnosis, treatment and various outcomes observed in a 10-year period.

\section{MATERIAL AND METHODS}

This is a retrospective study with an overview of medical files from pa- 
tients who were admitted and treated at the University Clinic of Toxicology and Urgent Internal Medicine, in Skopje, Republic of Macedonia, in the period from 2000 to 2009.

The variables measured and analyzed include: age, sex, type and amount of ingested agent, cause of ingestion (intended or accidental), types of diagnostic procedures used, prominent symptoms, grades of post-corrosive injuries, early and late post-corrosive complications.

Patients in the acute phase were hospitalized in intensive care and underwent urgent esophagogastroduodenoscopy in the first 24 hours. The post-corrosive injuries were categorized according to Kikendal classification (Table 1). The standard of procedure, for patients with intentional ingestion, is psychiatric evaluation prior to hospital release.

Esophagogastroduodenoscopy was performed by experienced medical staff with flexible endoscope, type Olimpus (Japan) with a diameter of 9,2mm. During the preparation of our patients, prior to the procedure, we used xylocaine gel for a better accomplishment of this invasive method. Techniques such as insufflations and retrovisualisation were performed very carefully due to the high risk of iatrogenic injuries. The quantity of ingested corrosive agent was determined by data carefully gathered through the form of a questionnaire, filled out by the patients and/or their families. Patients were asked to compare the amount of ingested chemical substance with one tablespoon, assuming that one tablespoon contains $15 \mathrm{ml}$. Symptoms presented at admission were noted in patients' clinical charts and according to the severity of the clinical presentation the poisonings were classified as simple, mild and severe. Simple intoxications were presented with signs like hyper salivation, difficulty in swallowing and pains in the oral cavity, throat, and behind the sternum. All cases that had additional symptoms like nausea were classified as mild poisonings, while patients with additional abdominal pain and hematemesis were classified as severe poisonings. Demographic characteristics such as age, type of chemical agent and intention for a corrosive substance abuse, were also determined and measured. According to the clinical appearance and degree of post-corrosive injuries of the upper GIT, all of the patients were treated with antibiotics, H2 blockers or protein pump inhibitors (PPI), intensive parenteral or enteral nutrition and symptomatic treatment. The patients where perforation occurred were transferred to the Clinic for digestive surgery, for a surgical intervention.

The data here gathered, was analyzed with an explanatory statistical method and the differences between the test groups were evaluated through the Mann-Whitney and KolmogorovSmirnov test.

\section{RESULTS}

In this study we evaluated 735 patients' charts for a 10 year period, from 01.01.2000 to 31.12.2009. Table 2 shows all clinical and demographic characteristics of our patients, year by year. The mean age ranges between $32.9 \pm 15.6$ years (mean $\pm \mathrm{SD}$ ), where the majority of patients are females $(n=524 ; 71.29 \%)$, and the minority are males $(n=211$; $28.7 \%$ ). Minimum age is 15 years, while maximum is 80 years. Highest education of patients ranks down as follows starting from the greatest percentage as secondary education $(n=445 ; 60.68$ $\%)$, followed by elementary school education ( $\mathrm{n}=263 ; 35.78 \%)$, and the least post-secondary education $(\mathrm{n}=26 ; 3.53$ $\%)$.

\begin{tabular}{|l|l|}
\hline Grade I & $\begin{array}{l}\text { mucosal edema and } \\
\text { erythema }\end{array}$ \\
\hline Grade IIA & $\begin{array}{l}\text { hemorrhage, erosions, } \\
\text { superficial ulcerations }\end{array}$ \\
\hline Grade IIB & circumferential lessions \\
\hline Grade III & $\begin{array}{l}\text { deep gray, brown or black } \\
\text { ulcers }\end{array}$ \\
\hline Grade IV & perforation \\
\hline
\end{tabular}

\section{Table 1. Kikendall classification}

According to their religious affiliation the majority were orthodox $(\mathrm{n}=385$; $52.38 \%)$, Muslim ( $\mathrm{n}=345 ; 46.93 \%)$, and others $(n=5 ; 0.68 \%)$. Our investigation showed that the greater number of patients ingested between 5 and $10 \mathrm{ml}$ $(n=482 ; 65.57 \%)$ of the chemical substance, the amount ranged between $16.8 \pm 8,6 \mathrm{ml}$, whereas minimal quantity was 5 , and maximal $50 \mathrm{ml}$. The majority of patients were admitted to hospi- tal 3 hours after the ingestion $(n=440$; $59.86 \%$; $<<0.001)$ and most of the patients abused the corrosive agent with suicidal intentions $(n=691 ; 94.01 \%$; $\mathrm{p}<0.001$ ) (Table 3).

Hydrochloric acid was most commonly used substance $(\mathrm{HCl} ; \mathrm{n}=354$; $48.16 \%$ ), while sodium hydroxide and sodium hypo chloride were used in lesser number of cases $(\mathrm{NaOH} ; \mathrm{n}=135$; 18.36\%; NaClO; $\mathrm{n}=149 ; 20.27 \%$ ). Distribution illustrates that the majority of patients ingested hydrochloric acid $(\mathrm{p}<0.001)$.

Urgent esophagogastroduodenoscopy (EGD) showed that at admission most of the patients are with IIA grade of injuries $(n=230 ; 31.29 \%)$ and IIB ( $\mathrm{n}=213 ; 28.97 \%)(\mathrm{p}<0.01)$, although at discharge the greater number of patients are with normal EGD findings $(\mathrm{n}=516 ; 70.20 \%)(\mathrm{p}<0.01)$. Unwanted outcome was reported in $\mathrm{n}=51$ or $6.9 \%$ of the patients.

Most of the patients presented the poisoning with mild clinical presentation $(\mathrm{n}=380 ; 51,7 \%)(\mathrm{p}<0.001)($ Table 4$)$.

\section{DISCUSSION}

Easy access to all kinds of corrosive agents and their institutional irregularities led to an increased number of corrosive poisonings. The faults and shortcomings of the policy for rules and regulations bound by law for the import of specific agents, licensing, packaging and stamping of those agents, allowed or caused for these dangerous corrosive agents to become the most often abused substances in everyday life $(9,10)$.

Results from this study showed that the incidence of acute corrosive intoxications is rising. The number of corrosive poisonings has increased and than fluctuated between $15 \%$ and $18 \%$ of all poisonings in Macedonia. Annual report of the American centre for poisoning control demonstrates that from the total number of reported poisonings 202056 are due to the abuse of cleaning agents, which are corrosive chemicals (11). A five year study made in Turkey (1996-2001) showed that $2.5 \%$ from the total number of poisonings $(n=1818)$ are result of corrosive substance ingestion (12).

These kinds of poisonings are frequently seen in the adult population, 


\begin{tabular}{|l|l|l|l|l|l|l|l|l|l|l|}
\hline Years & 2000 & 2001 & 2002 & 2003 & 2004 & 2005 & 2006 & 2007 & 2008 & 2009 \\
\hline Gender & $\mathrm{n}-\%$ & $\mathrm{n}-\%$ & $\mathrm{n}-\%$ & $\mathrm{n}-\%$ & $\mathrm{n}-\%$ & $\mathrm{n}-\%$ & $\mathrm{n}-\%$ & $\mathrm{n}-\%$ & $\mathrm{n}-\%$ & $\mathrm{n}-\%$ \\
\hline Male & $3(20.3)$ & $21(31.8)$ & $19(27.9)$ & $21(29.5)$ & $24(20.6)$ & $25(30.08)$ & $26(30.23)$ & $20(28.1)$ & $22(27.5)$ & $20(29.8)$ \\
\hline Female & $51(79.6)$ & $45(68.18)$ & $49(72)$ & $50(70.4)$ & $57(70.9)$ & $56(69.1)$ & $60(69.76)$ & $51(71.8)$ & $58(72.5)$ & $47(70.1)$ \\
\hline Age & & & & & & & & & & \\
\hline $14-30$ & $24(37.5)$ & $25(37.8)$ & $29(42.6)$ & $26(36.6)$ & $38(46.9)$ & $38(46.9)$ & $38(46.9)$ & $38(46.9)$ & $38(46.9)$ & $22(32.8)$ \\
\hline $30-45$ & $19(29.6)$ & $22(33.3)$ & $22(33.3)$ & $28(39.4)$ & $25(30.8)$ & $25(30.8)$ & $25(30.8)$ & $25(30.8)$ & $25(30.8)$ & $16(238)$ \\
\hline $45-60$ & $14(21-8)$ & $11(16.6)$ & $11(16.6)$ & $9(12.6)$ & $11(13.5)$ & $11(13.5)$ & $11(13.5)$ & $11(13.5)$ & $11(13.5)$ & $18(26.8)$ \\
\hline$>60$ & $7(10.93$ & $8(12.1)$ & $8(12.1)$ & $8(11.2)$ & $7(8.64)$ & $7(8.64)$ & $7(8.64)$ & $7(8.64)$ & $7(8.64)$ & $11(16.4$ \\
\hline & & & & & & & & & & \\
\hline Education & & & & & & & & & & \\
\hline Primary & $20(31.25)$ & $24(36.36)$ & $20(29.41)$ & $20(29.41)$ & $25(30.86)$ & $25(30.86)$ & $25(30.86)$ & $34(47.8)$ & $34(47.8)$ & $25(37.3)$ \\
\hline Secondary & $42(65.62)$ & $40(60.6)$ & $45(66.17)$ & $45(66.17)$ & $55(67.9)$ & $55(67.9)$ & $55(67.9)$ & $36(50.7)$ & $36(50.7)$ & $39(58.2)$ \\
\hline Post- Sec. & $2(3.12)$ & $2(3.03)$ & $3(4.41)$ & $3(4.41)$ & $1(1.23)$ & $1(1.23)$ & $1(1.23)$ & $1(1.4)$ & $1(1.4)$ & $3(4.4)$ \\
\hline & & & & & & & & & & \\
\hline Religion & & & & & & & & & \\
\hline Christian & $28(43.75)$ & $25(37.3)$ & $44(64.7)$ & $40(56.33)$ & $46(56.79)$ & $39(48.14)$ & $39(48.14)$ & $39(48.14)$ & $44(55)$ & $42(62.6)$ \\
\hline Muslim & $36(56.25)$ & $39(58.2)$ & $24(35.29)$ & $29(40.84)$ & $34(41.97)$ & $40(49.38)$ & $40(49.38)$ & $40(49.38)$ & $36(45)$ & $25(37.3)$ \\
\hline Others & $/$ & $3(4.4)$ & $/$ & $2(2.81)$ & $1(1.23)$ & $2(2.46)$ & $2(2.46)$ & $2(2.46)$ & $/$ \\
\hline Total & $64(100)$ & $66(100)$ & $68(100)$ & $71(100)$ & $81(100)$ & $81(100)$ & $86(100)$ & $71(100)$ & $80(100)$ & $67(100)$ \\
\hline
\end{tabular}

Table 2. Clinical and demographic characteristics

although similar findings can be seen among children. Data from a study conducted in England, Wales, suggests that one third of the total number of recoded poisonings is caused by household cleaning supplies (13).

Corrosive poisonings may cause serious post corrosive injuries of the upper gastrointestinal tract, along with very significant variables that can magnify the results such as age, gender, amount of ingested substance, duration of exposure, time interval between beginning of the treatment and evaluation of the damages with urgent esophagogastroduodenoscopy (14).

In our study the ratio between females and males is 2.5:1. Dominance of women who ingested corrosive agents, due to various reasons, is confirmed in number of other studies made in different part of the world including Asia and Latin America $(15,16)$.

Age analysis showed that the majority of patients are between 14 and 30 years of age, which that the highest risk group represents the developing population in the most productive and effective period.

A research made in Taiwan illustrated that the greater number of patients are with a mean age of 40 years and that among younger patients late post corrosive injuries and complications are more often and more severe (17).
Number of registered corrosive poisonings is positively correlated with patients' educational degree. Poisonings are more often recorded in individuals with lower educational degree and in the rural part of the country, where corrosive agents are also not controlled legally. The data implies that patients with elementary or secondary education at most, are the ones to resort to corrosive agents and poison them selves with them. Unlike patients with postsecondary education such as uni-

\begin{tabular}{|l|l|l|l|l|}
\hline $\begin{array}{l}\text { Amount (ml) } \\
\mathrm{n}(\%) ; \text { Std. } \\
\text { Dev. }\end{array}$ & $5-10$ & $10-30$ & $>30$ & \\
\cline { 2 - 5 } & $482(65.57)$ & $204(27.75)$ & $49(6.66)$ & $16.8 \pm 8.6 \mathrm{ml}$ \\
\hline $\begin{array}{l}\text { Hospitaliza- } \\
\text { tion (h) } \\
\mathrm{n}(\%) ;(p)\end{array}$ & After 1-3 & After 3-6 & After $>6$ & \\
\cline { 2 - 5 } & $440(59.86)$ & $126(17.14)$ & $169(22.99)$ & $\mathrm{p}<0.001$ \\
\hline $\begin{array}{l}\text { Motive } \\
\mathrm{n}(\%) ;(p)\end{array}$ & Suicidal & Accidentally & Other & \\
\cline { 2 - 5 } & $691(94.01)$ & $44(5.98)$ & $/$ & $\mathrm{p}<0.001$ \\
\hline
\end{tabular}

Table 3. Ingested amount, moment of hospitalization and motive for the poisoning

\begin{tabular}{|c|c|c|c|c|c|}
\hline \multicolumn{3}{|c|}{ Type of corrosive agent } & \multicolumn{3}{|c|}{ Post corrosive complications } \\
\hline & $\mathrm{n}$ & $\%$ & & $\mathrm{n}$ & $\%$ \\
\hline $\begin{array}{l}\mathrm{HCl} \\
\mathrm{NaOH} \\
\mathrm{CH} 3 \mathrm{COOH} \\
\mathrm{H} 2 \mathrm{SO} 4 \\
\mathrm{NaClO} \\
\mathrm{H} 2 \mathrm{O} 2 \\
\mathrm{p}<0.01\end{array}$ & $\begin{array}{l}354 \\
135 \\
83 \\
8 \\
149 \\
6\end{array}$ & $\begin{array}{l}48.16 \\
18.36 \\
11.29 \\
1.08 \\
20.27 \\
0.81\end{array}$ & $\begin{array}{l}\text { Normal findings } \\
\text { Stenosis } \\
\text { oesophagei } \\
\text { Stenosis ventriculi } \\
\text { Stenosis oesophaei } \\
\text { et ventriculi } \\
\text { Exitus letalis } \\
p<0.01\end{array}$ & $\begin{array}{l}516 \\
64 \\
56 \\
48 \\
51\end{array}$ & $\begin{array}{l}70.20 \\
8.7 \\
7.61 \\
6.53 \\
6.9\end{array}$ \\
\hline \multicolumn{3}{|c|}{ Injuries of upper GIT at admission } & \multicolumn{3}{|c|}{ Severity of the poisoning } \\
\hline & $\mathrm{n}$ & $\%$ & & $\mathrm{n}$ & $\%$ \\
\hline $\begin{array}{l}\mathrm{HCl} \\
\mathrm{NaOH} \\
\mathrm{CH} 3 \mathrm{COOH} \\
\mathrm{H} 2 \mathrm{SO} 4 \\
\mathrm{NaClO} \\
\mathrm{H} 2 \mathrm{O} 2 \\
\mathrm{p}<0.01\end{array}$ & $\begin{array}{l}354 \\
135 \\
83 \\
8 \\
149 \\
6\end{array}$ & $\begin{array}{l}48.16 \\
18.36 \\
11.29 \\
1.08 \\
20.27 \\
0.81\end{array}$ & $\begin{array}{l}\text { Normal findings } \\
\text { Stenosis } \\
\text { oesophagei } \\
\text { Stenosis ventriculi } \\
\text { Stenosis oesophaei } \\
\text { et ventriculi } \\
\text { Exitus letalis } \\
p<0.01\end{array}$ & $\begin{array}{l}516 \\
64 \\
56 \\
48 \\
51\end{array}$ & $\begin{array}{l}70.20 \\
8.7 \\
7.61 \\
6.53 \\
6.9\end{array}$ \\
\hline
\end{tabular}

Table 4. Type of corrosive agent, clinical findings at admission and discharge and severity of the poisoning versity degrees, whos number is almost insignificant.

Same studies made in Brazil and Turkey showed that the number of corrosive poisonings is greater in the rural areas in which the corrosive substances are used more often during every day life and where the public regulative is not appreciated (18).

In Macedonia, which is multi-confessional country, there is no difference between Christians and Muslims; despite the religion all individuals may 
abuse corrosive substance. According to religious affiliation we found difference in usage of various corrosive agents like acids or alkalis, which are used for various sanitary purposes or within the food production industry. (19).

The amount of ingested corrosive substance, time interval between moment of ingestion and admission to hospital, also the intention for the abuse are of great importance for prognosis of the poisonings' outcome. In our group of patients the ingested amount was between 5 and $10 \mathrm{ml}$, time interval was between 1 and 3 hours and the intention was mainly suicidal. The motive for corrosive substance abuse is often related to the amount of ingested agent. Usually when the substance is taken due to a suicidal intention the amounts are always large, despite the situations when ingestion happened accidentally and the amounts are generally quite lower. Among children poisonings are always accidental, but in adult population they are usually suicidal. According to information from different countries, the motive for corrosive agents abuse depends on development of the country and patients' educational structure. In countries which are on a low developmental level and among patients with lower educational degree poisonings are generally with suicidal intentions. On the other hand, patients with high educational degree and in high developed countries ingested the substance accidentally (20).

Percentage of late post corrosive complications is directly related to the amount of ingested chemicals and time interval between moment of ingestion and admission to hospital. Occurrence of stenosis of the upper gastrointestinal tract depends on quantity of ingested corrosive substance and time interval between admission to hospital and initiation of the treatment $(21,22)$.

We are determined that intake of 5 to $10 \mathrm{ml}$ can cause mild damages of the upper GIT, while amount of 10 to $20 \mathrm{ml}$ can cause serious post corrosive injuries. Intake of $30 \mathrm{ml}$ or more can end lethally during the acute phase, if not it will cause serious post corrosive complications and long term disability. One study, illustrated that the ingestion of
$50 \mathrm{ml}$ causes very serious and fatal post corrosive injuries, despite amounts like $15-30 \mathrm{ml}$ and less that cause mild and severe damages (23).

Our survey showed that most often abused corrosive substance is hydrochloric acid, less frequent sodium hydroxide and sodium hypochlorite. Similar studies around the world demonstrated that in European countries and USA we usually see poisonings which are result of ingestion of bases, which are found in cleaning products. On the other hand a mong countries like Macedonia or India poisonings are due to acids abuse, also used in households (24).

In our group of patients the poisonings are generally mild (presented with hyper salivation, difficulty in swallowing, pains in mouth, throat, and behind the sternum, nausea), the grades of post corrosive injuries usually are IIA and IIB, according to Kikendall classification, and most often the patents experience complete recovery. Current treatments (antibiotics, proton pump inhibitors, $\mathrm{H}_{2}$ blockers, intensive hyper alimentation and esophageal rest) help us achieve complete recovery and healing while decreasing the percentage of late post corrosive complications.

Golden standard among diagnostic procedures is the urgent esophagogastroduodenoscopy performed in the first 12-24 hours after the poisoning. Despite documented clinical signs the endoscopic result is of a great importance in localizing of the post corrosive damages and determination of their deepness. However, when there are signs of esophageal or gastric perforation, performing upper endoscopy is not obligatory. Urgent esophagogastroduodenoscopy has become the main and safest diagnostic procedure which can be used in treatment planning and provides some predictions for the potential post corrosive complications and mortality rate $(25,26)$. Results from many different studies showed that the severity of the injuries is correlated with the type of corrosive agent, its concentration, time of exposure and reason for ingestion(accidental or suicidal) $(27,28)$.

Corrosive substances cause tissue destruction as a result of coagulative and colliquative necrosis. We still report high percentages of late post cor- rosive complications, between $15 \%$ and $85 \%$. The mortality rates are still high, despite the intensive therapy, effective care, sophisticated diagnostic and therapeutically approach. Literature reports different numbers for mortality rates in the interval 2-10\%. Greater number of studies, created in order to evaluate the severity of post corrosive complications, showed that despite the high risk in the acute phase, the poisoning may end fatally even during the chronic phase as a result of malnutrition. Regardless of decreasing number of post corrosive injuries, we still have patients with very serious and severe damages of the upper GIT and they often end with life-long disabilities (29, 30).

\section{CONCLUSION}

Women seem to abuse corosive agents twice as much as men. Poisonings can be seen in every age, but most often they occur between young people, in the most effective and most creative period of their lives. They can happen in every religious group and are more often seen among people with low educational degree. Amount of ingested agent, time interval between moment of ingestion and admission to hospital, also the motive for chemicals abuse, remain important features which determine the severity of the poisoning and its outcome. Endoscopic evaluation at admission, during hospitalization and after discharge remains the golden standard for diagnosis, choice of treatment and prognosis of the poisoning.

Unfortunately, despite modern therapeutically protocols, usage of sophisticated methods for diagnosis and treatment, the high percentage of post corrosive complications is still a great challenge for doctors who follow and treat this problem.

\section{REFERENCES}

1. Kikendall J N. Caustic ingestion injuries. Gastroenterol Clin North Am. 1991; 20: 847-857.

2. Andreoni B, Marini A, Gavinelli M, Biffi R, Tiberio G, Farina, Rossi A Emergency management of caustic ingestion in adults. Surg Today. 1995, 25: 119-124.

3. Ertekin C, Alimoglu O, Akyildiz H, Guloglu R, Taviloglu K. The results of caustic ingestions. Hepatogastroenterology. 2004; 51: 1397-1400.

4. Dekovic I, Curcic M, Molnar M, Duda- 
sovic J. Suicides and attemted suicides with corrosive substances 1968-2001; Med Preg. 2001; 54: 155-160.

5. Chibishev A, Simonovska-Veljanovska N, Pereska Z. Artificial Nutrition in Therapeutic Approach of Acute Caustic Poisonings. Macedonian Journal of Medical Sciences. 2010; 3: 180-187.

6. Zwischenberger, Joseph B, Savage C, Bidan A. Surgical Aspects of Esophageal Disease. Am J Respir Crit Care Med. 2002, 165: 1037-1040.

7. Zargar SA, Kochhar R, Mehta S, Mehta SK. The role of fiberoptic endoscopy in the management of corrosive ingestion and modified endoscopic classification of burns. Gastrointest Endosc. 37: 165-169.

8. Ramasamy K, Gumaste VV. Corrosive ingestion in adults. J Clin Gastroenterol. 2003; 37: 119-124.

9. Ananthakrishnan N, Subba Rao KSVK, Radjendiran P. Mid-colon esophagocoloplasty for corrosive esophageal strictures. N Z J Surg. 1993; 63: 389-395.

10. Ananthakrishnan N, Parthasarathy G, Vikram K. Chronic Corrosive Injuries of the Stomach - A Single Unit Experience of 109 Patients Over Thirty Years, World J Surg. 2010; 34: 758-764.

11. Bronstein A, Spyker A, Louis R, Cantilena JR, Green J. Rumack B, Dart R. 2010 Annual Report of the American Association of Poison Control Centers' National Poison Data System (NPDS): 28th Annual Report Clinical Toxicology, 2011, 49: 910-941.

12. Akkose S, Bulut M, Armagan E, Cebicci $\mathrm{H}$, Fedakar R. Acute poisoning in adults in the years 1996-2001 treated in the Uludag University Hospital, Marmara Region, Turkey. Clin Toxicol (Phila). 2005; 43: 105-109.

13. Stiff G, Alwafi A, Rees BI, Lari J. Cor- rosive injuries of the oesophagus and stomach: experience in management at aregional paediatric centre. Ann R Coll Surg Engl. 1996; 78: 119-123.

14. Keh SM, Onyekwelu N, McManus K, McGuigan J. Corrosive injury to upper gastrointestinal tract: still a major surgical dilemma. World J Gastroenterol. 2006; 12: 5223-5228.

15. Rodríguez MA, Meza Flores JL. Clinicalepidemiological characteristics in caustics ingestion patients in the Hipólito Unanue National Hospital. Clinic Rev Gastroenterol Peru. 2003; 23: 115-125.

16. Ertekin C, Alimoglu O, Akyildiz H, Guloglu R, Taviloglu K. The results of caustic ingestions. Hepatogastroenterology. 2004; 51: 1397-400.

17. Chang JM, Liu NJ, Pai BC, Liu YH, Tsai $\mathrm{MH}$, Lee CS, Chu YY, Lin CC, Chiu CT, Cheng HT. The role of age in predicting the outcome of caustic ingestion in adults: a retrospective analysis. BMC Gastroenterol. 2011; 11: 72.

18. Mamede RCM, De Mello Filho FV. Treatment of caustic ingestion: an analysis of 239 cases , Diseases of the Esophagus. 2002; 15: 210-213.

19. Arevalo-Silva C, Eliashar R, Wohlgelernter J, Elidan J, Gross M. Ingestion of Caustic Substances: A 15-Year Experience Laryngoscope. 2006; 116: 14221426.

20. Cibisev A, Nikolova-Todorova Z, Bozinovska C, Petrovski D, Spasovski G. Epidemiology of severe poisonings caused by ingestion of caustic substances. Prilozi. 2007; 28: 171-183.

21. Tohda G, Sugawa C, Gayer C, Chino A, McGuire TW, Lucas CE, Clinical evaluation and management of caustic injury in the upper gastrointestinal tract in 95 adult patients in an urban medical cen- ter. Surg Endosc. 2008; 22: 1119-1125.

22. Rafee M, Shoaran M, Eghbali E . Clinical charact eristics and complications in oral caustic ingestion in children, Urmia Medical Journal. 2009; 20: 131-136.

23. Berthet $\mathrm{B}$, Bernardini $\mathrm{D}$, Lonjon $\mathrm{T}$ et al. Traitement desste'noses caustiques du tractus digestif supe' rieur. J Chirurgie. 1995; 132: 447-450.

24. Ananthakrishnan N, Parthasarathy G, Kate V. Acute corrosive injuries of the stomach: a single unit experience of thirty years. ISRN Gastroenterol. 2011; 2011: 914-1013.

25. Poley JW, Steyerberg EW, Kuipers EJ, Dees J, Hartmans R, Tilanus HW, Siersema PD. Ingestion of acid and alkaline agents: outcome and prognostic value of early upper endoscopy. Gastrointest Endosc. 2004; 60: 372-377.

26. Zargar SA, Kochhar R, Nagi B, Mehta S, Mehta SK. Ingestion of strong corrosive alkalis: spectrum of injury to upper gastrointestinal tract and natural history. American Journal of Gastroenterology. 1992; 87: 337-341.

27. Ertekin Alimoglu O, Akyildiz H, Guloglu R, Taviloglu K. The results of caustic ingestions. Hepatogastroenterology. 2004, 51: 1397-400.

28. Mattos GM, Lopes DD, Mamede RCM, Ricz H, Mello-Filho FV, Neto JB. Effects of time of contact and concentration ofcaustic agent on generation of injuries. Laryngoscope. 2006; 116: 456-460.

29. Goldman LP, Weigert JM. Corrosive substance ingestion: a review. American Journal of Gastroenterology. 1984; 79: 85-90.

30. Agarwal S, Sikora SS, Kumar A, Saxena $\underline{R}$, Kapoor VK. Surgical management of corrosive strictures of stomach. Indian I Gastroenterol. 2004; 23: 178-180. 